\title{
Effects of Excess Mg and Si on the Isothermal Ageing Behaviours in the Al-Mg $\mathrm{Mg}_{2} \mathrm{Silloys}$
}

\author{
Long Chau Doan*, Kiyomichi Nakai, Yoshitsugu Matsuura*, Sengo Kobayashi and Yasuya Ohmori \\ Department of Materials Science and Engineering, Ehime University, Matsuyama 790-8577, Japan
}

\begin{abstract}
The effects of excess $\mathrm{Mg}$ and $\mathrm{Si}$ contents on the isothermal ageing processes of $\mathrm{Al}-\mathrm{Mg}_{2} \mathrm{Si}$ alloys have been investigated by means of transmission electron microscopy and the following results were obtained. After the formation of $\beta^{\prime \prime}$ needles inducing large age hardening, cuboid $\beta$ particles precipitate in both the excess $\mathrm{Mg}$ and the quasi-binary alloys, but fine $\mathrm{Si}$ particles nucleate in the excess $\mathrm{Si}$ alloys. In the quasi-binary alloy, the following reaction is the precipitation of $\beta^{\prime}$ rods and then $\beta$ plates form. In the excess Si alloys, various rodlike precipitates form after the precipitation of $\beta^{\prime \prime}$ needles and Si particles in the sequence: Type-A rods $\rightarrow$ Type-B rods $\rightarrow \beta^{\prime}$ rods. This precipitation sequence can be understood by considering the chemical compositions of them determined by Matsuda et al.
\end{abstract}

(Received February 6, 2002; Accepted April 24, 2002)

Keywords: aluminum-magnesium-silicon alloys, isothermal ageing, $\beta^{\prime \prime}$ needles, cuboid $\beta$ particles, $\beta^{\prime}$ rods, Type-A rods, Type-B rods, $\beta-\mathrm{Mg}_{2}$ Si plates

\section{Introduction}

The phases precipitating in $\mathrm{Al}-\mathrm{Mg}_{2} \mathrm{Si}$ quasi-binary alloys have been reported as monoclinic $\beta^{\prime \prime}$ needles, hexagonal $\beta^{\prime}$ rods and $\beta-\mathrm{Mg}_{2} \mathrm{Si}$ plates. ${ }^{1-6)}$ In addition to these particles, some other intermediate phases precipitate. Cuboid $\beta-\mathrm{Mg}_{2} \mathrm{Si}$ particles ${ }^{7,8)}$ have been frequently observed in the alloys containing excess $\mathrm{Mg}$ atoms and also in the quasi-binary alloys. In the excess Si alloys, however, Matsuda et al. reported that Type-A, B and C particles $^{9-12)}$ form as well.

The crystal structures of intermediate phases can be summarised as follows. For $\beta^{\prime \prime}$ phase, the results so far reported are rather diversified. ${ }^{11,13-17)}$ Wahi et al. ${ }^{14)}$ reported that the structure was monoclinic with the lattice parameters $a=c=0.616 \mathrm{~nm}, b=0.710 \mathrm{~nm}$ and $\beta=82^{\circ}$. According to Lynch et al., ${ }^{15)}$ however, the lattice parameters were determined as: $a=0.300, b=0.330, c=0.400 \mathrm{~nm}$ and $\gamma=71.00^{\circ}$. On the other hand, Andersen ${ }^{16)}$ examined $\beta^{\prime \prime}$ phase needles by means of high-resolution transmission electron microscopy (HRTEM) and reported that the structure and its space group are monoclinic with the lattice parameters $a=1.516, b=0.405, c=0.674 \mathrm{~nm}$ and $\beta=105.30^{\circ}$, and $\mathrm{C} 2 / \mathrm{m}$, respectively. Matsuda et al. ${ }^{11)}$ obtained the lattice parameters $a=0.77, b=0.67, c=0.203 \mathrm{~nm}$ and $\gamma=75^{\circ}$ by HRTEM analysis and determined the space group as $\mathrm{P} 2 / \mathrm{m}$. The result almost similar to that by Matsuda was also obtained by Maruyama et al., ${ }^{17)}$ i.e., the lattice parameters are $a=0.714, b=0.658, c=0.405 \mathrm{~nm}$ and $\gamma=75^{\circ}$, and the space group is $\mathrm{P} 2 / \mathrm{m}$.

On the structure of $\beta^{\prime}$ phase, Jacobs ${ }^{2)}$ showed that the $\beta^{\prime}$ phase has a hexagonal unit cell with the lattice parameters $a=0.705$ and $c=0.405 \mathrm{~nm}$. In the same temperature range where $\beta^{\prime}$ rods form, Matsuda et al. reported that Type-A, $\mathrm{B}$ and $\mathrm{C}$ rods form in excess Si alloys. ${ }^{9-12)}$ The structure of Type-A phase is hexagonal with $a=0.405$ and $c=0.67 \mathrm{~nm}$, that of Type-B is orthorhombic with $a=0.684, b=0.793$ and $c=0.405 \mathrm{~nm}$, and Type-C phase has a hexagonal unit cell with $a=1.04$ and $c=0.405 \mathrm{~nm}$.
Although the precipitation reactions in $\mathrm{Al}-\mathrm{Mg}-\mathrm{Si}$ alloys have been the subjects of numerous investigations, most of them are concerned with either a specific specimen or certain ageing conditions and the effects of chemical composition, ageing temperature and time on the precipitation of various intermediate phases processes during isothermal ageing have not been fully understood. Thus, in the present study, precipitation sequences of intermediate phases during isothermal aging in the $\mathrm{Al}-\mathrm{Mg}_{2} \mathrm{Si}$ alloys are examined by means of conventional transmission electron microscopy (TEM).

\section{Experimental Procedures}

The chemical compositions of the $\mathrm{Al}-\mathrm{Mg}-\mathrm{Si}$ alloys used are shown in Table 1 . The ingots were homogenised at $560^{\circ} \mathrm{C}$ for $12 \mathrm{~h}$ and were rolled to $1 \mathrm{~mm}$ thick plates at room temperature. In order to discuss the effects of solutionising on the precipitation processes, the chemical compositions of the present alloys were compared with the solubility limit of $\beta-\mathrm{Mg}_{2} \mathrm{Si}$ in $\alpha$-solid solution at $560^{\circ} \mathrm{C}$ (Fig. 1). The specimens machined from the plates of the alloys 2, 4 and 6 were solution-treated at $560^{\circ} \mathrm{C}$ for $30 \mathrm{~min}$ and quenched into iced water. Those of the alloys 1, 3, 5 and part of the alloy 4 specimens were solutionised at $590^{\circ} \mathrm{C}$ for $30 \mathrm{~min}$. These specimens were aged isothermally in an alloy bath kept at temperatures from 150 to $350^{\circ} \mathrm{C}$ immediately after the quenching.

Vickers hardness measurements and TEM observation

Table 1 Chemical composition of Al-Mg-Si alloy (at\%).

\begin{tabular}{cccccc}
\hline Mark & $\mathrm{Mg}$ & $\mathrm{Si}$ & $\mathrm{Mg}_{2} \mathrm{Si}$ & Excess Si & Excess Mg \\
\hline Alloy 1 & 1.30 & 0.38 & 1.14 & - & 0.54 \\
\hline Alloy 2 & 1.48 & 0.48 & 1.44 & - & 0.52 \\
\hline Alloy 3 & 1.32 & 0.42 & 1.26 & - & 0.48 \\
\hline Alloy 4 & 0.82 & 0.47 & 1.23 & 0.06 & - \\
\hline Alloy 5 & 1.20 & 0.90 & 1.80 & 0.30 & - \\
\hline Alloy 6 & 0.93 & 1.03 & 1.39 & 0.57 & - \\
\hline
\end{tabular}




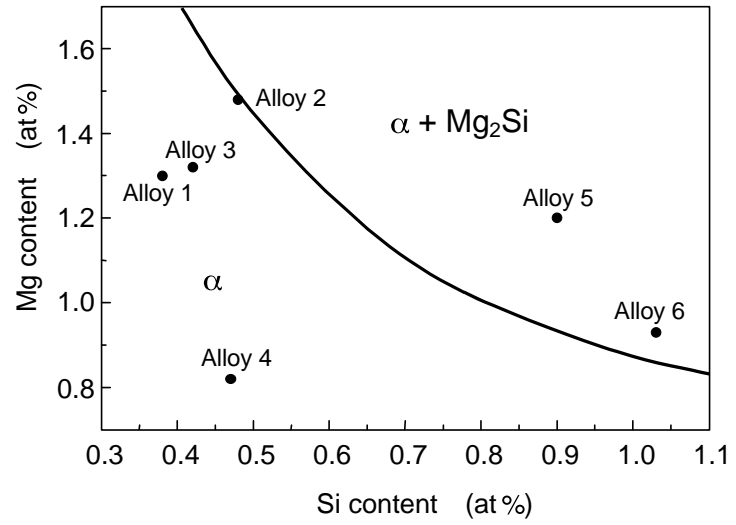

Fig. 1 The solid solubility limit for $\mathrm{Mg}_{2} \mathrm{Si}$ within the $\mathrm{Al}$ rich solid solution at $560^{\circ} \mathrm{C}$. The chemical compositions for the alloys used in the present study are plotted in the figure.

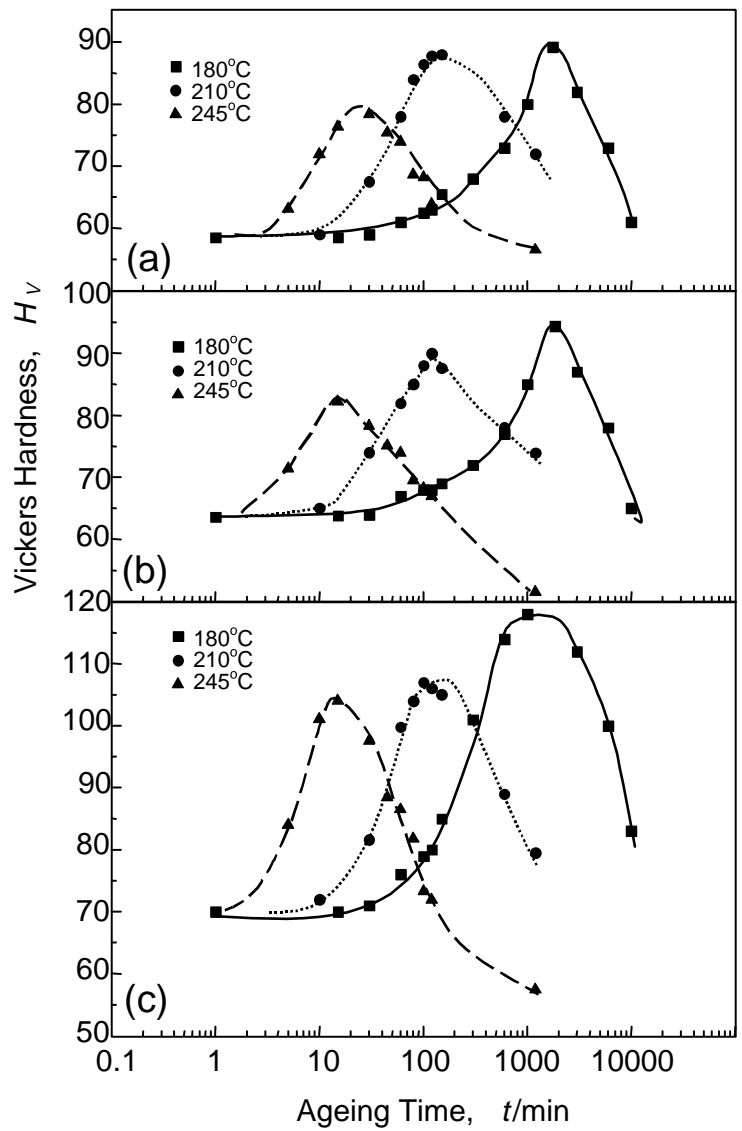

Fig. 2 Variation of hardness with ageing time after the solution-treatment at $560^{\circ} \mathrm{C}$. (a) Excess $\mathrm{Mg}$ alloy 2, (b) quasi-binary alloy 4 and (c) excess $\mathrm{Si}$ alloy 6.

were carried out for the specimens aged at various temperatures. Thin foils for TEM were prepared by electrolytic polishing in the mixture of three parts of methanol and one part of $\mathrm{HNO}_{3}$ at $-30^{\circ} \mathrm{C}$ and were examined in a JEOL-2000EX microscope operating at $200 \mathrm{kV}$.

\section{Experimental Results}

\subsection{Vickers hardness measurements}

Figures 2(a) to (c) show the variations of Vickers hardness with ageing time for the excess $\mathrm{Mg}$ alloy 2, the quasi-binary

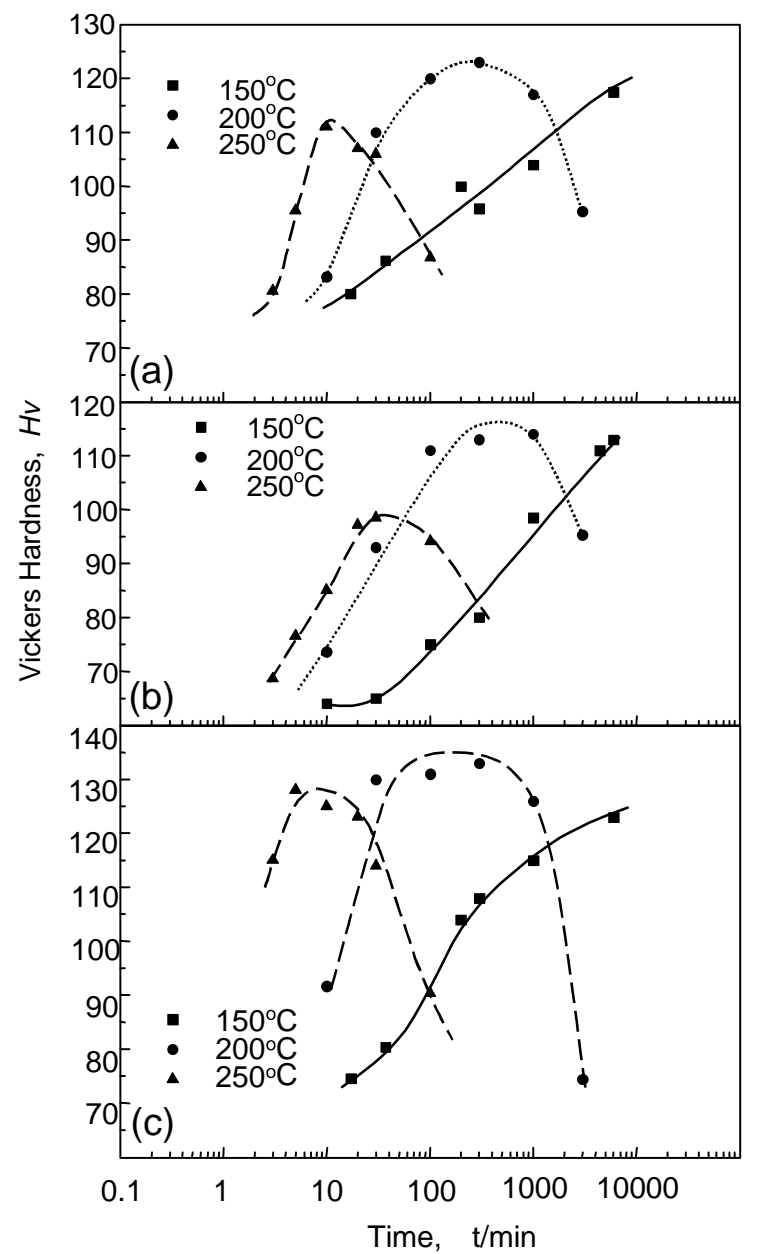

Fig. 3 Variation of hardness with ageing time after the solution-treatment at $590^{\circ} \mathrm{C}$. (a) Excess $\mathrm{Mg}$ alloy 1, (b) quasi-binary alloy 4 and (c) excess $\mathrm{Si}$ alloy 5 .

$\mathrm{Al}-\mathrm{Mg}_{2} \mathrm{Si}$ alloy 4 and the excess Si alloy 6 aged at temperatures between 185 and $245^{\circ} \mathrm{C}$ after the solution treatments at $560^{\circ} \mathrm{C}$, respectively. The hardness variations during isothermal ageing for the excess $\mathrm{Mg}$ alloy 1, the quasi-binary alloy 4 and the excess Si alloy 5 solutionised at $590^{\circ} \mathrm{C}$ are also shown in Fig. 3. The ageing temperatures in this case are 150, 200 and $250^{\circ} \mathrm{C}$. All the specimens exhibited a similar hardening sequence. The maximum hardness values, however, exhibit quite complicated compositional dependence. In the case of solutionising at $560^{\circ} \mathrm{C}$, the maximum hardness increased with increasing the excess $\mathrm{Si}$ content. The alloys solution-treated at $590^{\circ} \mathrm{C}$ exhibited the maximum hardness much higher than those solutionised at $560^{\circ} \mathrm{C}$. It should be noted that even the hardness of the quasi-binary alloy 4 which can be completely solutionised at $560^{\circ} \mathrm{C}$ as in Fig. 1 is increased by ageing at $590^{\circ} \mathrm{C}$ (compare Fig. 2(b) with Fig. 3(b)) and that both the excess $\mathrm{Mg}$ and $\mathrm{Si}$ contents increase the peak hardness in comparison with that of the quasi-binary alloy in the case of $590^{\circ} \mathrm{C}$ solution-treatment.

\subsection{TEM observation}

\subsubsection{The precipitation of intermediate phases in the ex-} cess Mg alloy

In the specimen aged at $210^{\circ} \mathrm{C}$, very fine $\beta^{\prime \prime}$ needles began to precipitate in accordance with the sharp hardening. Well- 


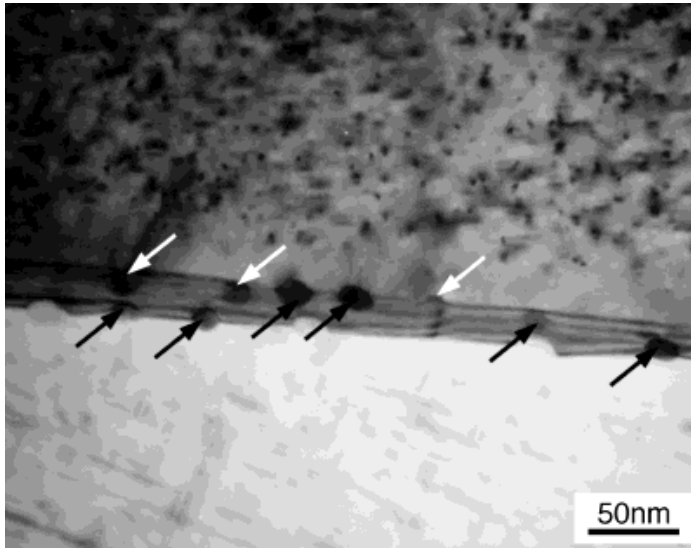

Fig. 4 Precipitation of cuboid $\beta$ particles at a grain boundary in the excess $\mathrm{Mg}$ alloy 2 aged at $210^{\circ} \mathrm{C}$ for $5 \mathrm{~h}$. Arrows indicate cuboid $\beta$ particles.

defined reflections from $\beta^{\prime \prime}$ needles, however, were not obtained at the initial stage of ageing. By ageing the alloy 2 at $210^{\circ} \mathrm{C}$ for $5 \mathrm{~h}$, cuboid $\beta$ particles precipitating on grain boundaries were clearly observed in addition to the $\beta^{\prime \prime}$ needles within the matrix (Fig. 4). In the specimens aged for $50 \mathrm{~h}$ at $210^{\circ} \mathrm{C}$, the reflections from $\beta^{\prime \prime}$ needles became much clearer. The bright field image, the selected area electron diffraction pattern and the dark field image using a $\beta^{\prime \prime}$ reflection are shown in Figs. 5(a), (b) and (c), respectively. The reflections from $\beta^{\prime \prime}$ needles can be indexed by using the lattice parameters determined by Andersen. ${ }^{16)}$ All the reflections and the orientation relationships between the $\beta^{\prime \prime}$ needles and the $\alpha$-matrix obtained in the present study were always in keeping with the structural model by Andersen. ${ }^{16)}$ The $\beta^{\prime \prime} / \alpha$-matrix (Al) relationships determined for $\beta_{1}^{\prime \prime}$ and $\beta_{2}^{\prime \prime}$ in the pattern Fig. 5(b) are very close to two different variants of that by Andersen: ${ }^{16)}$

$$
\begin{aligned}
& {[010]_{\beta^{\prime \prime}} \|[001]_{\mathrm{A} 1} \cdots \cdot \text { growth direction, }} \\
& (001)_{\beta^{\prime \prime}}\left\|(320)_{\mathrm{A} 1}, \quad(100)_{\beta^{\prime \prime}}\right\|(\overline{1} 30)_{\mathrm{A} 1}
\end{aligned}
$$

The above relationship is exactly satisfied between $\beta_{1}^{\prime \prime}$ and the matrix. In a different area of the same specimen, cuboid $\beta$ particles ${ }^{7,8)}$ were also observed within the matrix as in Fig. $6(a)$. The selected area electron diffraction pattern indicates that the cuboid $\beta$ particles were related to the Al matrix with the cube-cube orientation relationship. The additional reflections in the pattern arose from the double diffraction between the $\beta$ particles and the matrix. In the later stages of ageing at this temperature, $\beta^{\prime}$ rods were occasionally observed.

Although the precipitation time was largely accelerated, a similar precipitation sequence was also observed in the case of ageing at $245^{\circ} \mathrm{C}$. The precipitates formed by further ageing at higher temperatures were mostly $\beta$ phase particles. The formation of Type-A, B and C rods could not be observed.

\subsubsection{The precipitation of intermediate phases in the quasi-binary alloy}

Figure 7 shows the $\beta^{\prime \prime}$ precipitation in the quasi-binary alloy 4 aged at $245^{\circ} \mathrm{C}$ for $2 \mathrm{~h}$. The dark field image using $(2 \overline{1} \overline{2})_{\beta^{\prime \prime} 1}$ and $(\overline{2} \overline{1} 2)_{\beta^{\prime \prime} 4}$ reflections and the selected area electron diffraction pattern are illustrated in Figs. 7(a) and (b), respectively. The diffraction pattern involved four variants of
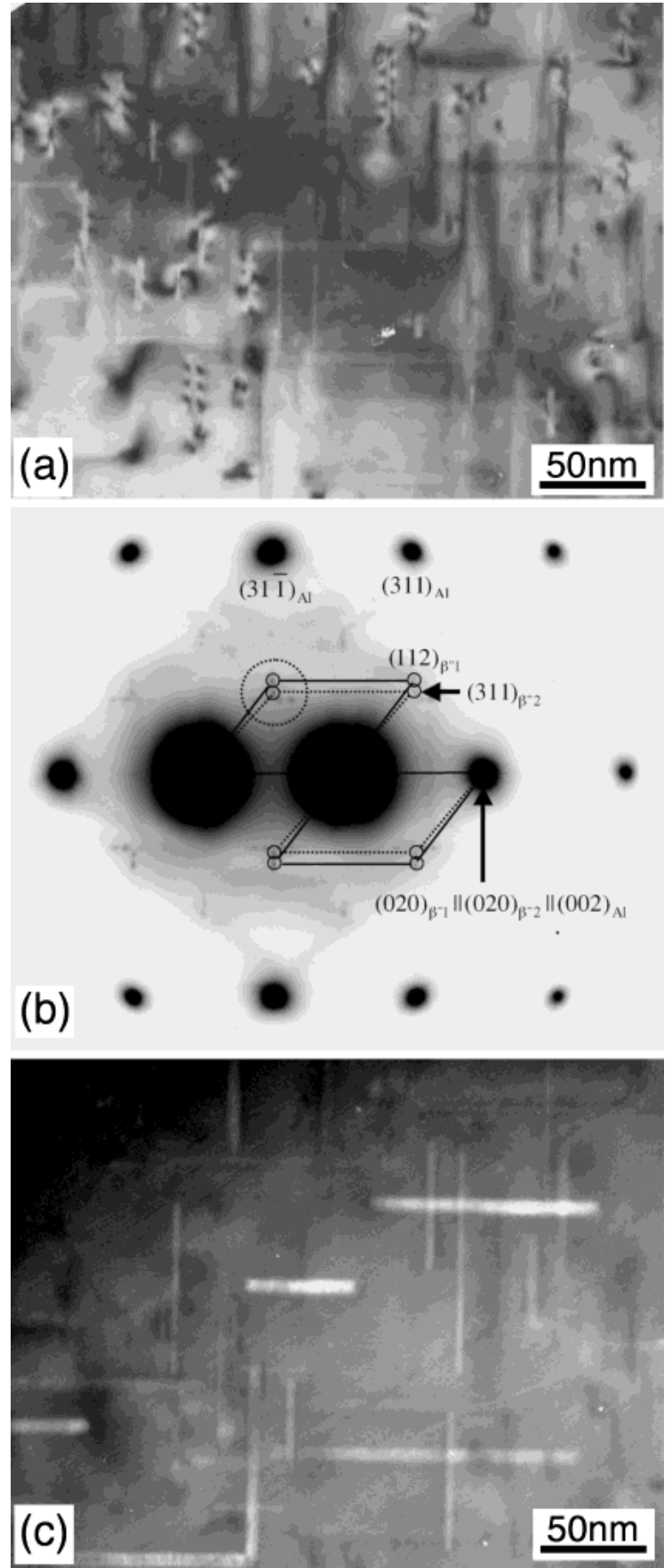

Fig. $5 \quad \beta^{\prime \prime}$ needles within the matrix in the excess $\mathrm{Mg}$ alloy 2 aged at $210^{\circ} \mathrm{C}$ for $50 \mathrm{~h}$. (a) Bright field image, (b) the selected area electron diffraction pattern and (c) the dark field image using the $\beta^{\prime \prime}$ reflections enclosed by broken circle.

Andersen's $\beta^{\prime \prime} / \mathrm{Al}$ orientation relationship ${ }^{16)}$ described above. In a different area of the same specimen, cuboid $\beta$ particles were observed as shown by arrows in Fig. 8. These $\beta$ particles were also related to the matrix by the cube-cube orientation relationship. ${ }^{7,8)}$ By further ageing at the same temperature, $\beta^{\prime}$ rods having a hexagonal crystal lattice precipitated. Figures 9(a) and (b) are the bright field image and the selected area electron diffraction pattern for the specimen aged at $245^{\circ} \mathrm{C}$ for $190 \mathrm{~h}$. $\beta^{\prime}$ rods elongated in the $\langle 100\rangle_{\mathrm{Al}}$ directions can be seen. The lattice parameters used for the analysis are due to those obtained by Jacobs. ${ }^{2)}$ The orientation relationship in this 

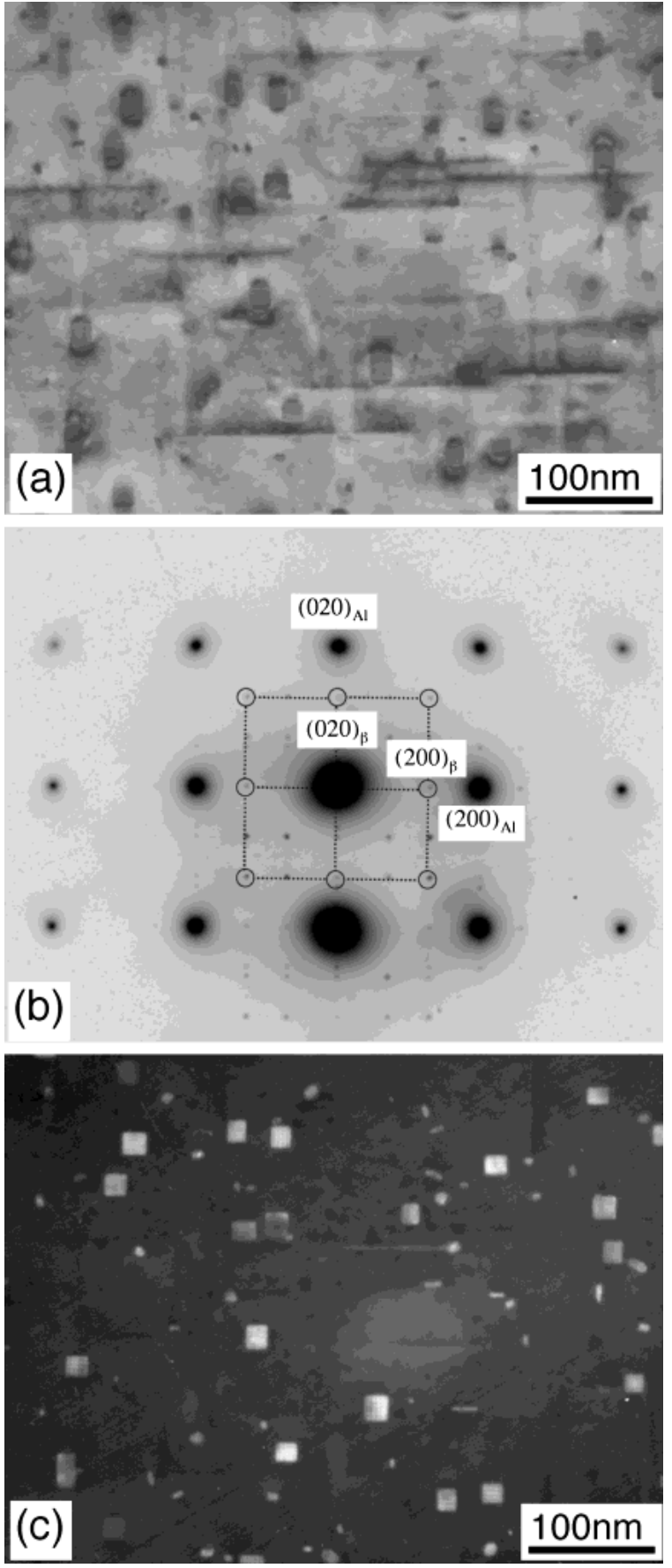

Fig. $6 \beta^{\prime \prime}$ needles and cuboid $\beta$ particles in the excess Mg alloy 2 aged at $210^{\circ} \mathrm{C}$ for $50 \mathrm{~h}$. (a) Bright field image using the $(220)_{\beta}$ reflection, (b) the selected area electron diffraction pattern and (c) the dark field image using the $(220)_{\beta} \beta$ reflection.

case can be expressed as:

$$
\begin{aligned}
& {[0001]_{\beta^{\prime}} \|[100]_{\mathrm{Al}} \cdots \cdots \text { growth direction, }} \\
& (01 \overline{10})_{\beta^{\prime}}\left\|(031)_{\mathrm{Al}},(\overline{2} 110)_{\beta^{\prime}}\right\|(0 \overline{1} 3)_{\mathrm{Al}}
\end{aligned}
$$

This relationship is in good agreement with that referred to as "middle range type" by Matsuda et al. ${ }^{19)}$ within an experimental error. In the specimens aged at $300^{\circ} \mathrm{C}$, the precipitation of $\mathrm{Mg}_{2} \mathrm{Si} \beta$ plates and $\beta^{\prime}$ rods were recognised. Figure 10(a) shows the $\beta$ plates formed in the specimen aged at $300^{\circ} \mathrm{C}$ for $2 \mathrm{~h}$. The habit plane of the plates is parallel to $\{100\}_{\mathrm{Al}}$ matrix plane but the edges of the plates incline
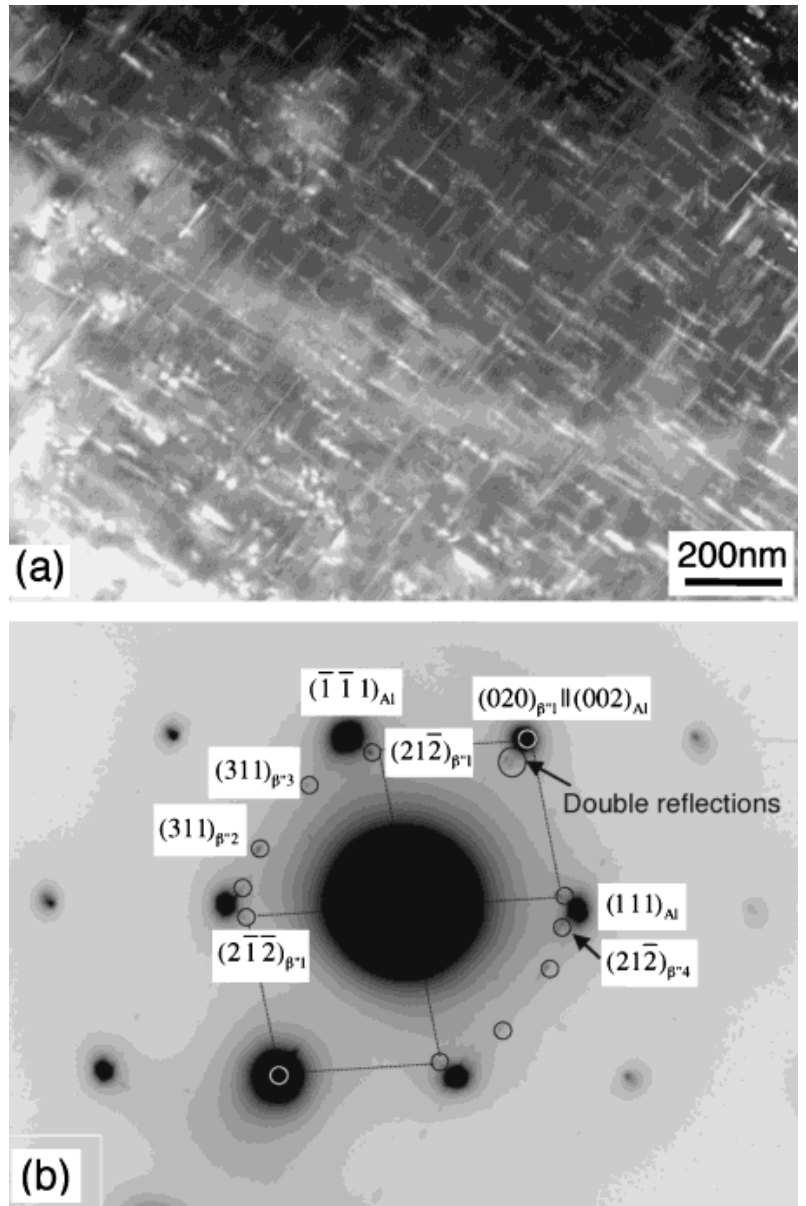

Fig. 7 Precipitation of $\beta^{\prime \prime}$ needles in the quasi-binary alloy 4 aged at $245^{\circ} \mathrm{C}$ for $2 \mathrm{~h}$. (a) Dark field image using $(2 \overline{1} \overline{2})_{\beta^{\prime \prime} 1}$ and $(\overline{2} \overline{1})_{\beta^{\prime \prime} 4}$ reflections, and (b) the selected area electron diffraction pattern.

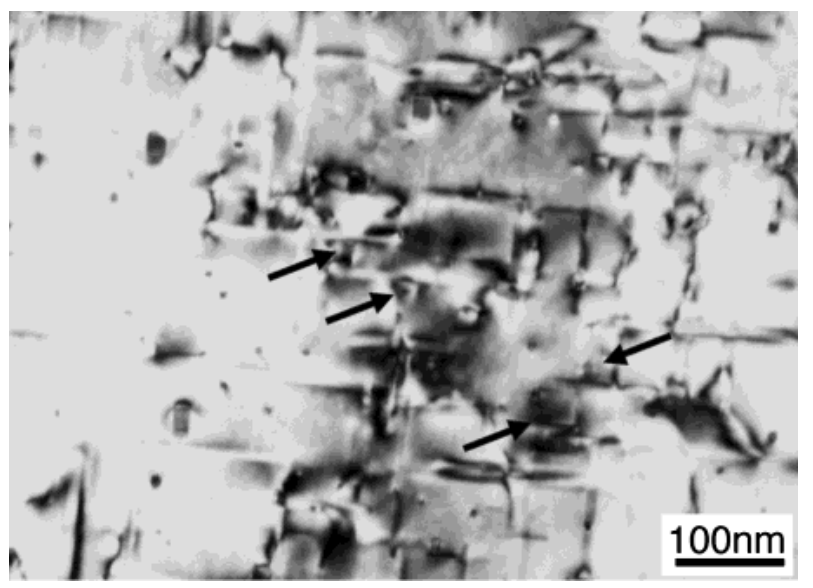

Fig. 8 Precipitation of cuboid $\beta$ particles in the quasi-binary alloy 4 aged at $245^{\circ} \mathrm{C}$ for $2 \mathrm{~h}$. Arrows indicate $\beta$ particles.

about $18^{\circ}$ from $\langle 100\rangle_{\mathrm{Al}}$ matrix directions as can be seen in the diffraction pattern (b). The orientation relationship between this plate and the matrix is very close to:

$$
\begin{aligned}
& (001)_{\beta} \|(001)_{\mathrm{Al}} \cdots \cdots \text { habit plane, } \\
& (100)_{\beta}\left\|(3 \overline{1} 0)_{\mathrm{Al}},(010)_{\beta}\right\|(130)_{\mathrm{Al}} \text {. }
\end{aligned}
$$

This agrees well with one of the relationships observed previously. ${ }^{8)}$ The edges of the plates are parallel to the $\langle 110\rangle_{\beta}$ 

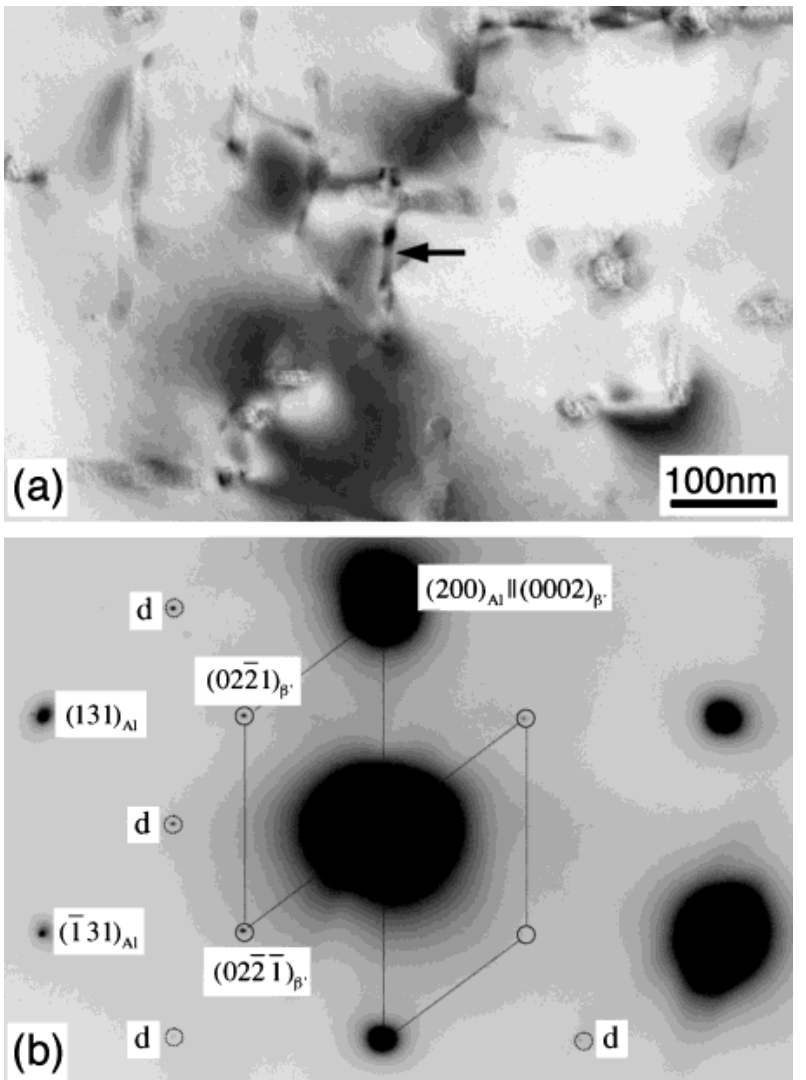

Fig. 9 Precipitation of $\beta^{\prime}$ rods in the quasi-binary alloy 4 aged at $245^{\circ} \mathrm{C}$ for $190 \mathrm{~h}$. Arrow indicates $\beta^{\prime}$ rod and double reflections are shown by "d". (a) Bright field image and (b) the selected area electron diffraction pattern.

directions. Figure 11(a) shows the $\beta^{\prime}$ rod observed in a different area in the same specimen. The orientation relationship obtained from the selected area electron diffraction pattern is one of the variants shown in Fig. 9(b).

\subsubsection{The precipitation of intermediate phases in the ex- cess Si alloys}

The precipitation sequence in the excess Si alloys was significantly different from those in the excess $\mathrm{Mg}$ and the quasibinary alloys as has been reported originally by Matsuda et al., ${ }^{9-12)}$ and various phases were also observed in the present study. In the alloy 6 aged at $210^{\circ} \mathrm{C}$ for $2 \mathrm{~h}, \beta^{\prime \prime}$ needles and fine dot-like particles were observed. Increasing the ageing time to $50 \mathrm{~h}$, the particles induced well-defined reflections. Figures 12(a), (b) and (c) are the bright field image of the alloy 6 aged at $210^{\circ} \mathrm{C}$ for $50 \mathrm{~h}$, the selected area electron diffraction pattern and the dark field image using the $(111)_{\mathrm{Si}}$ reflection, respectively. The diffraction pattern (b) consists of the reflections from the matrix, those from $\beta^{\prime \prime}$ needles and those from Si particles. The orientation relationship between $\beta^{\prime \prime}$ needles and the matrix was determined by using one of the net patterns from $\beta^{\prime \prime}$ needles as shown by the broken lines in the pattern, and was confirmed to be exactly the same as the Andersen's relationship ${ }^{16)}$ described above. The net pattern comprising well-defined reflections and solid lines, however, was indexed as those from Si particles. The dark field illumination using a $\mathrm{Si}$ reflection indicates that fine Si particles with the same orientation dispersed in the specimen as shown in Fig. 12(c). The orientation relationship between Si parti-

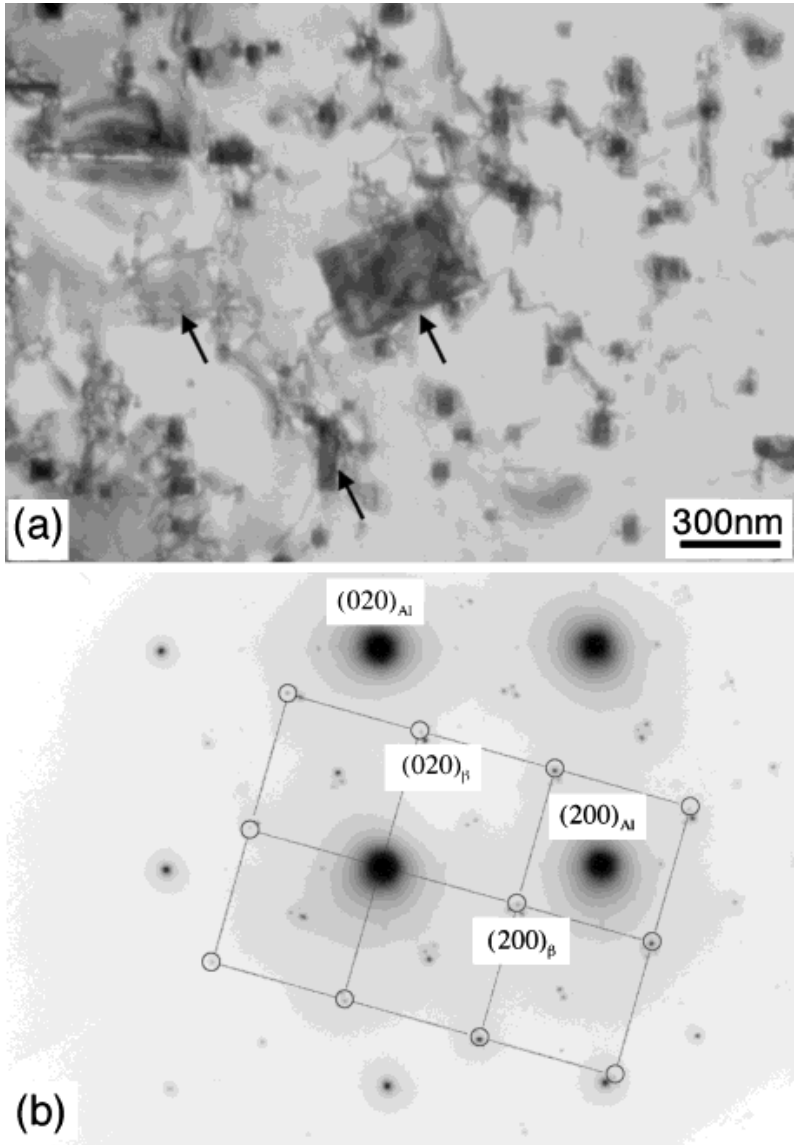

Fig. 10 Precipitation of $\beta$ plates in the quasi-binary alloy 4 aged at $300^{\circ} \mathrm{C}$ for $2 \mathrm{~h}$. Arrows indicate $\beta$ plates. (a) Bright field image and (b) the selected area electron diffraction pattern.

cles and the matrix is given as:

$$
(\overline{1} 10)_{\mathrm{Si}}\left\|(\overline{1} 10)_{\mathrm{Al}},(111)_{\mathrm{Si}}\right\|(110)_{\mathrm{Al}},(\overline{1} \overline{1} 2)_{\mathrm{Si}} \|(001)_{\mathrm{Al}}
$$

This is quite far from the relationship determined by Matsuda et al. ${ }^{21)}$

$$
(111)_{\mathrm{Si}} \|(001)_{\mathrm{Al}},[\overline{1} 10]_{\mathrm{Si}} 10^{\circ} \text { from[100] } \mathrm{Al}
$$

The isothermal holding at $210^{\circ} \mathrm{C}$ for longer times induced the precipitation of Type-A rods ${ }^{11)}$ with diameters as large as $30-80 \mathrm{~nm}$ in addition to $\beta^{\prime \prime}$ needles. Figure 13(a) shows both the longitudinal figure and the cross section of Type-A rods in the excess Si alloy 5 aged at $210^{\circ} \mathrm{C}$ for $150 \mathrm{~h}$. The diffraction patterns in Fig. 13(b) indicate that the Type-A/matrix orientation relationships were very close to the two different variants of the orientation relationship determined by Matsuda et al. ${ }^{11)}$ and can be expressed as:

$$
\begin{aligned}
& {[1 \overline{2} 10]_{\mathrm{A}_{1}} \|[0 \overline{1} 0]_{\mathrm{Al}} \cdots \cdot \text { growth direction, }} \\
& (0001)_{\mathrm{A}_{1}}\left\|(301)_{\mathrm{Al}},(\overline{1} 010)_{\mathrm{A}_{1}}\right\|(\overline{1} 03)_{\mathrm{Al}} \\
& {[\overline{2} 110]_{\mathrm{A}_{2}} \|[001]_{\mathrm{Al}} \cdots \cdots \text { growth direction, }} \\
& (0001)_{\mathrm{A}_{2}}\left\|(\overline{1} 30)_{\mathrm{Al}},(0 \overline{1} 10)_{\mathrm{A}_{2}}\right\|(310)_{\mathrm{Al}} .
\end{aligned}
$$

The Type-A rods were also observed in the excess Si alloy 6 aged at $210^{\circ} \mathrm{C}$ for $400 \mathrm{~h}$. In the specimen aged at $245^{\circ} \mathrm{C}, \beta^{\prime \prime}$ needles were still observed to exist. Figure 14 is an example of $\beta^{\prime \prime}$ needles in the alloy 6 aged at $245^{\circ} \mathrm{C}$ for $2 \mathrm{~h}$. The growth 

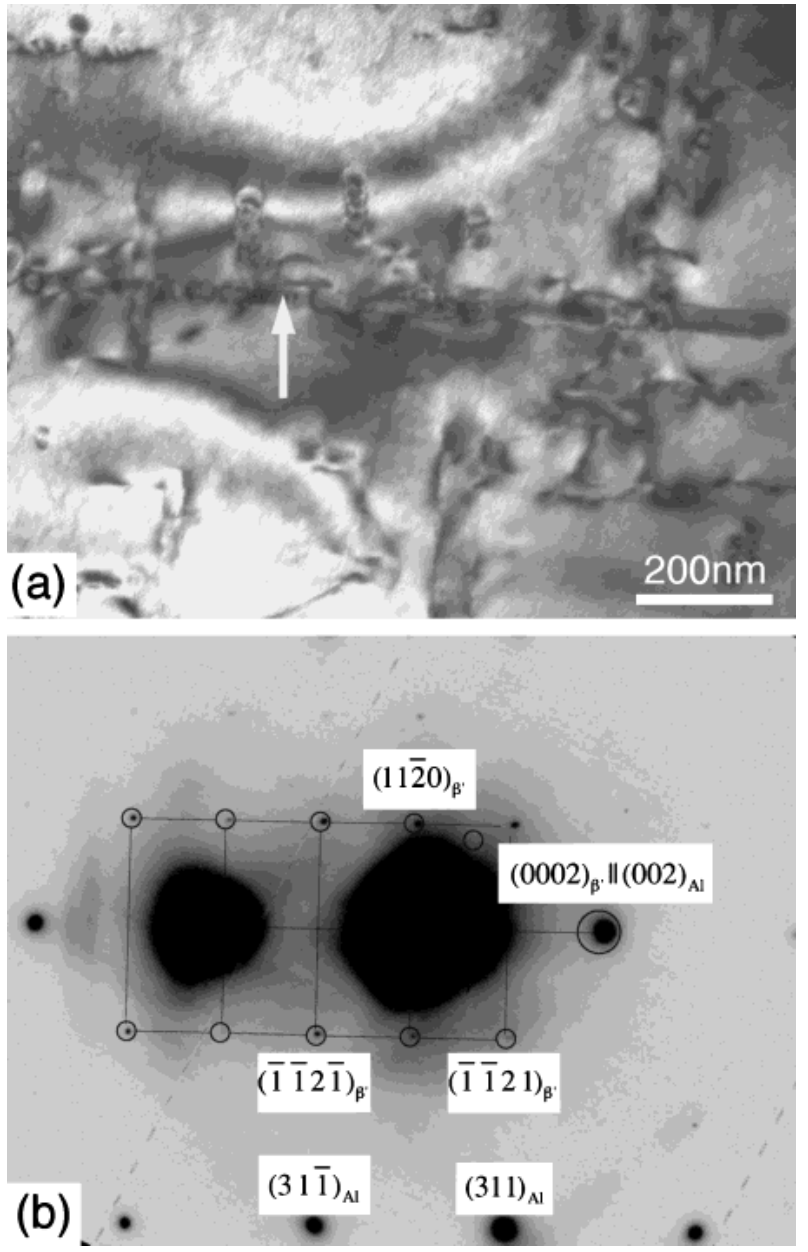

Fig. 11 Precipitation of $\beta^{\prime}$ rods in the quasi-binary alloy 4 aged at $300^{\circ} \mathrm{C}$ for $10 \mathrm{~h}$. Arrow indicates $\beta^{\prime}$ rod. (a) Bright field image and (b) the selected area electron diffraction pattern.

directions are parallel to $\langle 100\rangle_{\mathrm{Al}}$ as in Fig. 14(a), and the needles elongated in the $[001]_{\mathrm{Al}}$ direction provided the diffraction pattern of $\beta^{\prime \prime}$ phase shown in Fig. 14(b). The $\beta^{\prime \prime} /$ matrix orientation relationship can be expressed as:

$$
\begin{aligned}
& {[010]_{\beta^{\prime \prime}} \|[001]_{\mathrm{Al}} \cdots \cdots \text { growth direction, }} \\
& (30 \overline{2})_{\beta^{\prime \prime}} \|(100)_{\mathrm{Al}} \text {. }
\end{aligned}
$$

This relationship is also close to Andersen's relationship, ${ }^{16)}$ i.e.,

$$
\begin{aligned}
& {[010]_{\beta^{\prime \prime}} \|[001]_{\mathrm{Al}} \cdots \cdot \text { growth direction, }} \\
& (001)_{\beta^{\prime \prime}}\left\|(\overline{3} \overline{2} 0)_{\mathrm{Al}},(100)_{\beta^{\prime \prime}}\right\|(\overline{1} 30)_{\mathrm{Al}}
\end{aligned}
$$

In the alloy 6 aged at $300^{\circ} \mathrm{C}$ for $4 \mathrm{~h}$, Type- $\mathrm{A}$ and $\mathrm{B}$ rods began to precipitate. The diameters of Type-A and $\mathrm{B}$ rods were as large as $100 \mathrm{~nm}$ and $10-30 \mathrm{~nm}$, respectively. The examples are shown in Figs. 15 and 16. Figure 15(a) shows the bright field image containing both the Type-A and B rods. It can be seen that the diameter of Type-A rod is much larger than that of Type-B rod but the growth directions of both the rods are exactly the same, i.e., $[010]_{\mathrm{Al}}$ direction. The orientation relationship between these rods and the matrix can be expressed as:
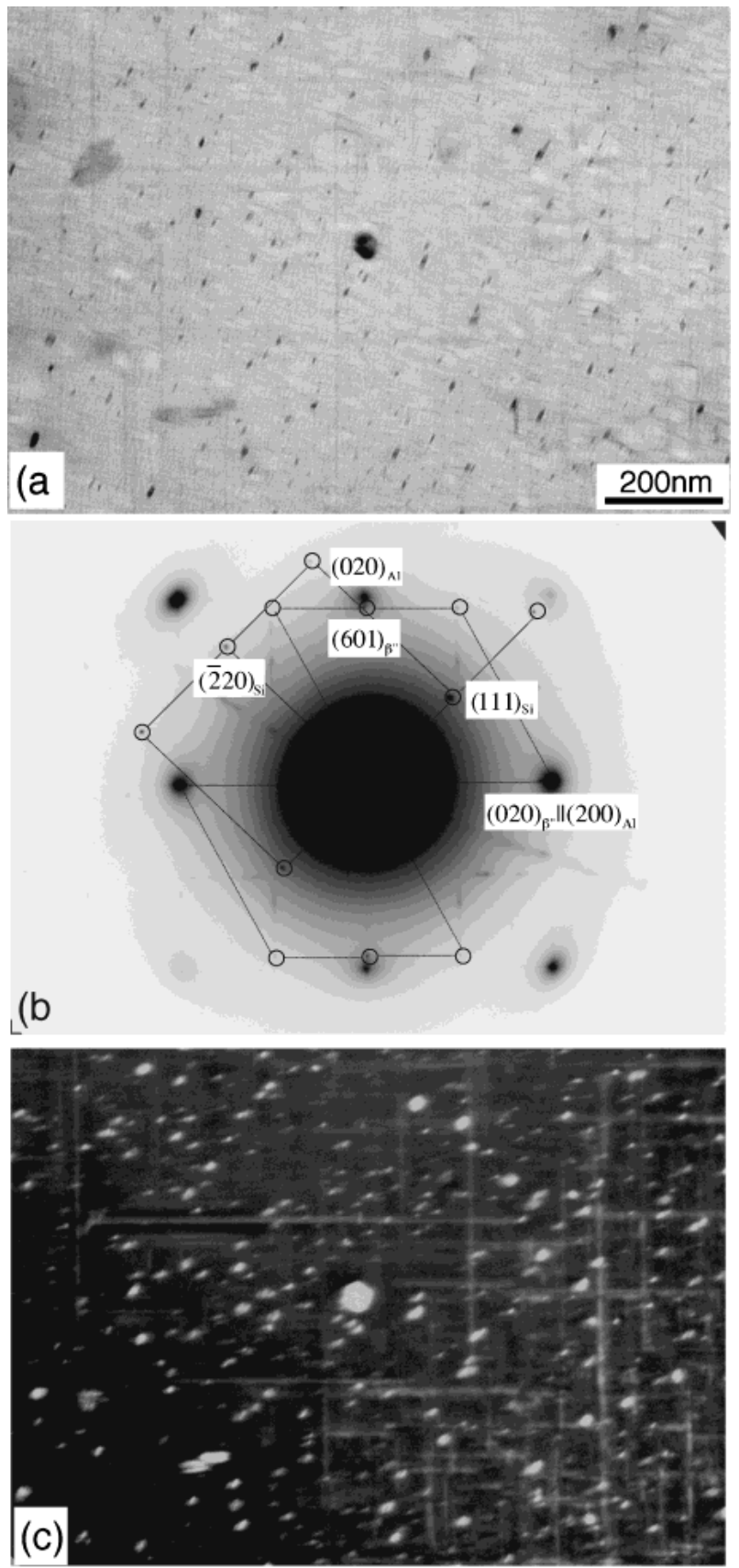

Fig. 12 Precipitation of Si particles and $\beta^{\prime \prime}$ needles in the excess Si alloy 6 aged at $210^{\circ} \mathrm{C}$ for $50 \mathrm{~h}$. (a) Bright field image, (b) the selected area electron diffraction pattern and (c) the dark field image using the $(111)_{\mathrm{Si}}$ reflection.

For Type-A $\operatorname{rod}:[1 \overline{2} 10]_{\mathrm{A}_{1}} \|[010]_{\mathrm{Al}} \ldots$. growth direction,

$$
(0001)_{\mathrm{A}_{1}}\left\|(\overline{3} 01)_{\mathrm{Al}},(\overline{1} 010)_{\mathrm{A}_{1}}\right\|(103)_{\mathrm{Al}}
$$

For Type-B rod : $[001]_{\mathrm{B}} \|[010]_{\mathrm{Al}} \cdots \cdots$ growth direction,

$$
(130)_{\mathrm{B}}\left\|(100)_{\mathrm{Al}},(2 \overline{1} 0)_{\mathrm{B}}\right\|(001)_{\mathrm{Al}}
$$

The Type-A/matrix orientation relationship is the same as that obtained above. The Type-B/matrix relationship is also very close to that obtained by Matsuda et al. ${ }^{11)}$ i.e.,

$[001]_{\mathrm{B}} \|[010]_{\mathrm{Al}} \cdots \cdots$ growth direction,

$(010)_{\mathrm{B}}$ about $20^{\circ}$ from $(100)_{\mathrm{Al}}$ 

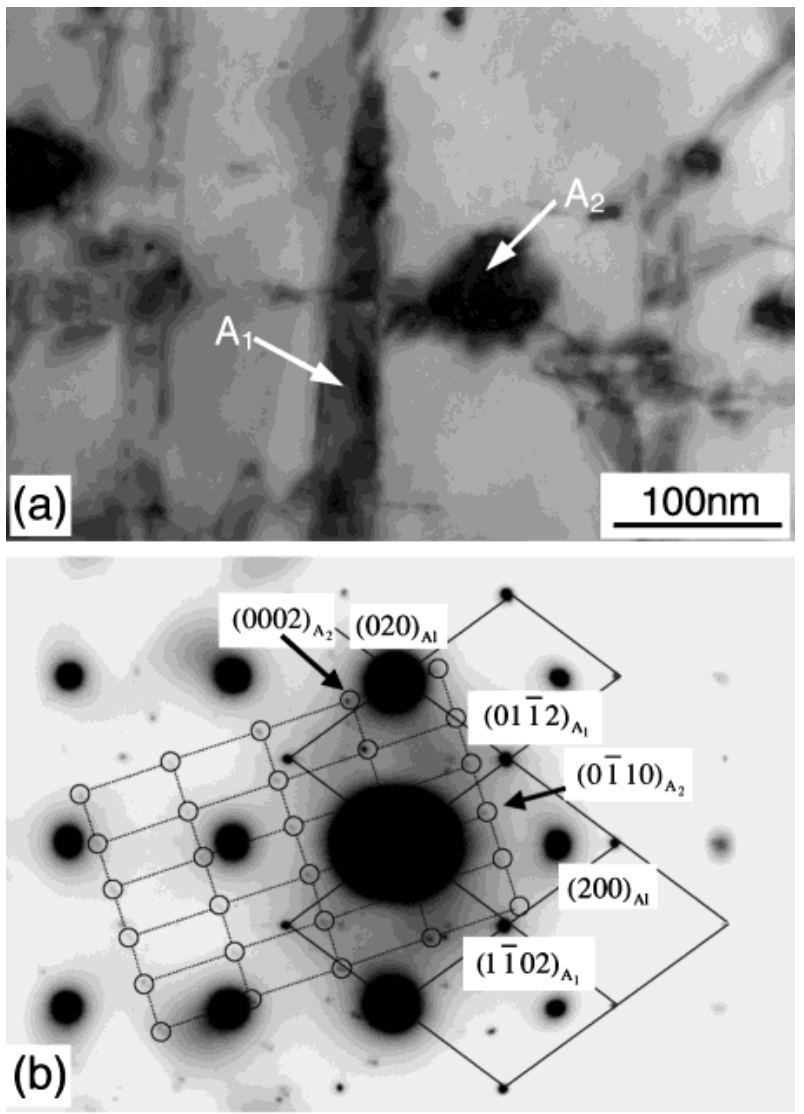

Fig. 13 Precipitation of Type-A rods in the excess $\mathrm{Si}$ alloy 5 aged at $210^{\circ} \mathrm{C}$ for $150 \mathrm{~h}$. (a) Bright field image and (b) the selected area electron diffraction pattern.

Figures 16(a) and (b) are the bright field image and the selected area electron diffraction pattern from a different area in the same specimen. Although the variants of the orientation relationship are different from those in Fig. 15, the equivalent orientation relationships of both Type-A/matrix and Type/B/matrix were obtained. The precipitation of Type$\mathrm{C}$ precipitates, however, could not be detected in the present experimental condition. Coarse $\mathrm{Si}$ particles were also clearly observed in the specimen aged at temperatures above $245^{\circ} \mathrm{C}$ for long time. An example in the alloy 6 aged at $300^{\circ} \mathrm{C}$ for $10 \mathrm{~h}$ is shown in Fig. 17. The bright field image and the selected area electron diffraction pattern are in Figs. 17(a) and (b), respectively. The morphology of the Si particle observed in (a) is quite similar to those observed by Matsuda et al. ${ }^{20)}$ and the edges of the polyhedral Si particle are parallel to the traces of $\{110\}_{\mathrm{Al}}$ matrix planes as pointed out by Matsuda et al. The Si/Al orientation relationship determined from the diffraction pattern (b), however, can be expressed as:

$$
(121)_{\mathrm{Si}}\left\|(\overline{100})_{\mathrm{Al}},(101)_{\mathrm{Si}}\right\|(01 \overline{3})_{\mathrm{Al}},(\overline{1} 01)_{\mathrm{Si}} \|(031)_{\mathrm{Al}}
$$

and is different from that by Matsuda $e t a l .^{20)}$ In the excess Si alloy 4 aged at $350^{\circ} \mathrm{C}$ for $4 \mathrm{~h}$, the formation of platelike $\beta$ has been observed. Figure 18 shows an example of a $\beta$ plate exhibiting a different orientation relationship. In this case, the edges of the plate are parallel to $\langle 100\rangle_{\mathrm{Al}} \|\langle 110\rangle_{\beta}$ directions and the relationship can be expressed as:

$$
(100)_{\mathrm{Al}}\left\|(110)_{\beta},(010)_{\mathrm{Al}}\right\|(\overline{1} 10)_{\beta},(001)_{\mathrm{Al}} \|(001)_{\beta} .
$$
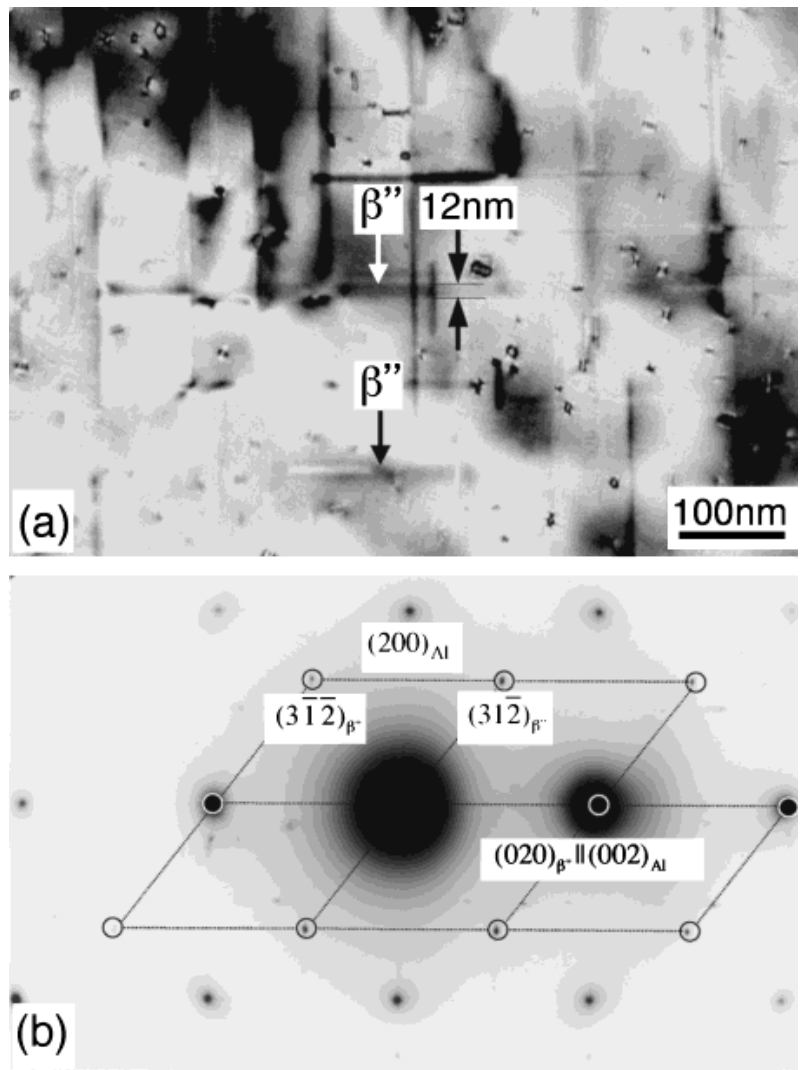

Fig. 14 Precipitation of $\beta^{\prime \prime}$ needles in the excess Si alloy 6 aged at $245^{\circ} \mathrm{C}$ for $2 \mathrm{~h}$. (a) Bright field image and (b) the selected area electron diffraction pattern.

This is in good agreement with that reported previously. ${ }^{7,8)}$

\section{Discussion}

In the previous continuous heating experiment, ${ }^{18)}$ the intermediate phases observed were limited, and the formation of Type-A and $\mathrm{C}$ rods could not be recognised. The phases precipitated during isothermal ageing processes are summarised in Table 2. Since age hardening is related to the precipitation processes, the relationship between hardness and the fine structures are examined.

As has been reported elsewhere, the maximum hardness is related to the amounts of $\beta^{\prime \prime}$ needles and the average size of them. Since $\beta^{\prime \prime}$ phase consists of $\mathrm{Mg}, \mathrm{Si}$ and $\mathrm{Al}$ atoms, ${ }^{9,11)}$ the amounts of $\beta^{\prime \prime}$ needles precipitated are thought to be dominated by the solubility product of $\mathrm{Mg}, \mathrm{Si}$ and $\mathrm{Al}$ atoms and the increase of either $\mathrm{Mg}$ or $\mathrm{Si}$ atoms will increase the amounts of $\beta^{\prime \prime}$ needles. The hardness, however, depends on the chemical composition in rather complicated manner. In order to compare the maximum hardness values, a complete solutionising of the precipitates is prerequisite. Thus, the chemical compositions were examined by the solubility limit curve for the stable $\beta-\mathrm{Mg}_{2} \mathrm{Si}$ precipitates as shown in Fig. 1. It is interesting to note that the composition of the excess $\mathrm{Mg}$ alloy 2, which shows the peak hardness lower than that of the quasi-binary alloy 4 , lies at a very critical region, indicating the possibility of the incomplete solutionising. The compositions of both the excess Si alloys 5 and 6 showing the peak hardness much higher than that of quasi-binary alloy 4 , how- 

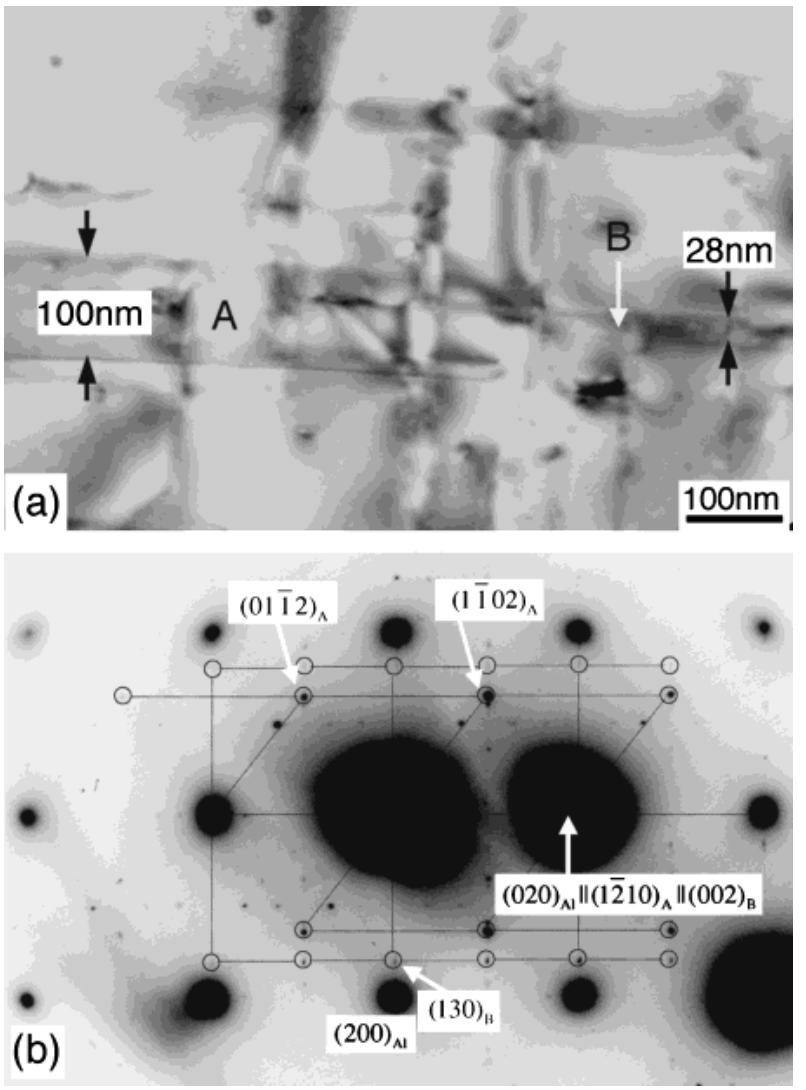

Fig. 15 Type-A and B rods in the excess Si alloy 6 aged at $300^{\circ} \mathrm{C}$ for $4 \mathrm{~h}$. (a) Bright field image and (b) the selected area electron diffraction pattern.

Table 2 The relationship between phases observed and ageing condition.

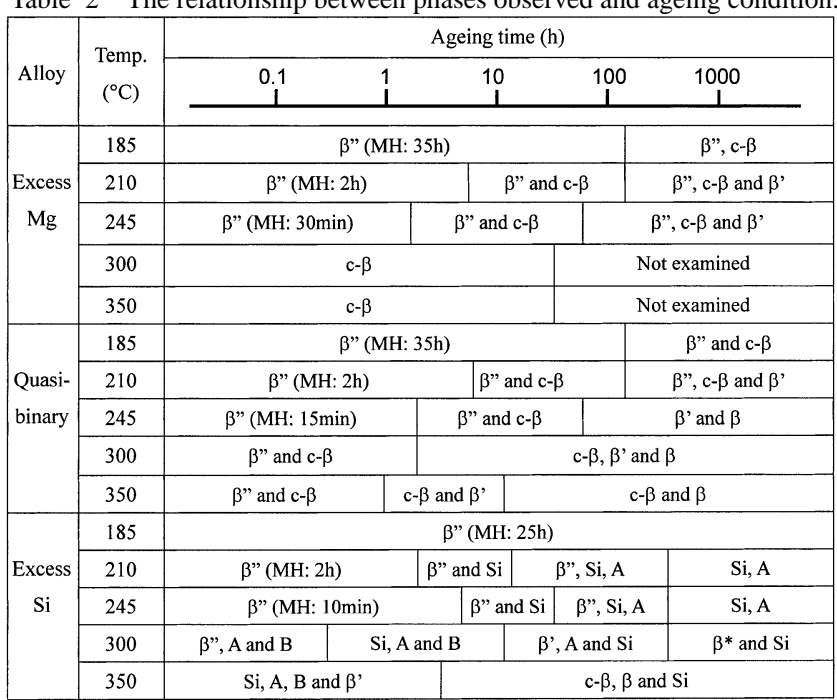

$\beta^{\prime \prime}$;" needles, c- $\beta$ : cuboid $\beta$ particles, $\beta$ : $\beta$ plates, $\beta^{*}$ : cuboid $\beta$ particles and $\beta$ plates, $\beta^{\prime}$ : $\beta^{\prime}$ rods, A Type-A rods, B: Type-B rods, Si: Si particles, MH: the ageing time showing the maximum hardness

ever, lie also in the region of incomplete solutionising. Thus, some other factors affecting the maximum hardness should be considered in addition to the incomplete solutionising. It should also be noted that in the excess $\mathrm{Mg}$ alloys cuboid $\beta$ $\mathrm{Mg}_{2} \mathrm{Si}$ particles precipitate separately at temperatures almost the same as those of $\beta^{\prime \prime}$ needles (Table 2). Therefore, when the undissolved $\beta$ - $\mathrm{Mg}_{2} \mathrm{Si}$ particles exist, $\mathrm{Mg}$ and $\mathrm{Si}$ atoms in the $\alpha$-solid solution will migrate to the undissolved precipitates to grow them and will consume the amounts of free $\mathrm{Mg}$
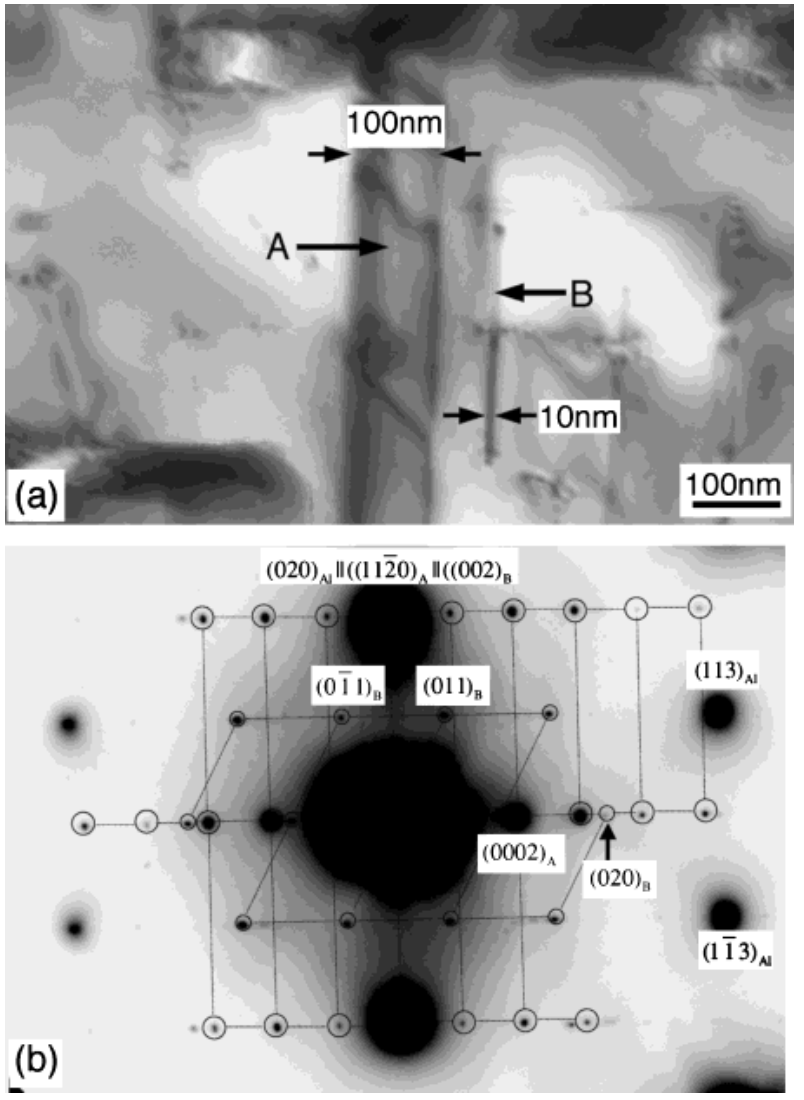

Fig. 16 Type-A and B rods in the excess Si alloy 6 aged at $300^{\circ} \mathrm{C}$ for $4 \mathrm{~h}$. (a) Bright field image and (b) the selected area electron diffraction pattern.

and $\mathrm{Si}$ atoms quite easily during the precipitation of $\beta^{\prime \prime}$ needles, reducing the amounts of $\beta^{\prime \prime}$ needles. This may be the reason of the reduction of the maximum hardness in the excess $\mathrm{Mg}$ alloy 2.

On the other hand, in the excess Si alloys, the formation of cuboid $\beta-\mathrm{Mg}_{2} \mathrm{Si}$ particles is largely suppressed at temperatures where $\beta^{\prime \prime}$ needles precipitate (Table 2). This, in other words, implies that the undissolved $\beta-\mathrm{Mg}_{2} \mathrm{Si}$ particles are difficult to grow at $\beta^{\prime \prime}$ formation temperatures and excess $\mathrm{Si}$ atoms will enhance the precipitation of $\beta^{\prime \prime}$ needles even in the incomplete solutionising condition. Furthermore, the $\beta^{\prime \prime}$ needles contain large amounts of $\mathrm{Si}$ atoms, i.e., $\mathrm{Si}: \mathrm{Al}: \mathrm{Mg}=$ 6:3:1, as reported by Matsuda et al.$^{9,11)}$ This will also accelerate the precipitation of $\beta^{\prime \prime}$ needles, resulting in the maximum hardness much higher than that if the quasi binary alloy even in the incomplete solutionising condition.

It should also be noted that the maximum hardness obtained in the excess $\mathrm{Mg}$ alloy 1 is much higher than that of the quasi-binary alloy 4 as can be seen in Figs. 2 and 3. In both the cases, the solution treatment temperatures were well within the $\alpha$-solid solution region, the difference existing in the vacancy concentration at the solutionising temperatures. If the vacancy clusters or the solute atom clusters which nucleated at vacancy clusters act as the nucleation sites for $\beta^{\prime \prime}$ needles, the density of them will be increased with raising the solution treatment temperature as in keeping with the experimental results.

The precipitation sequence is examined in the order of increasing ageing temperature. Since the precipitation of cuboid $\beta-\mathrm{Mg}_{2} \mathrm{Si}$ particles has been discussed in detail in 

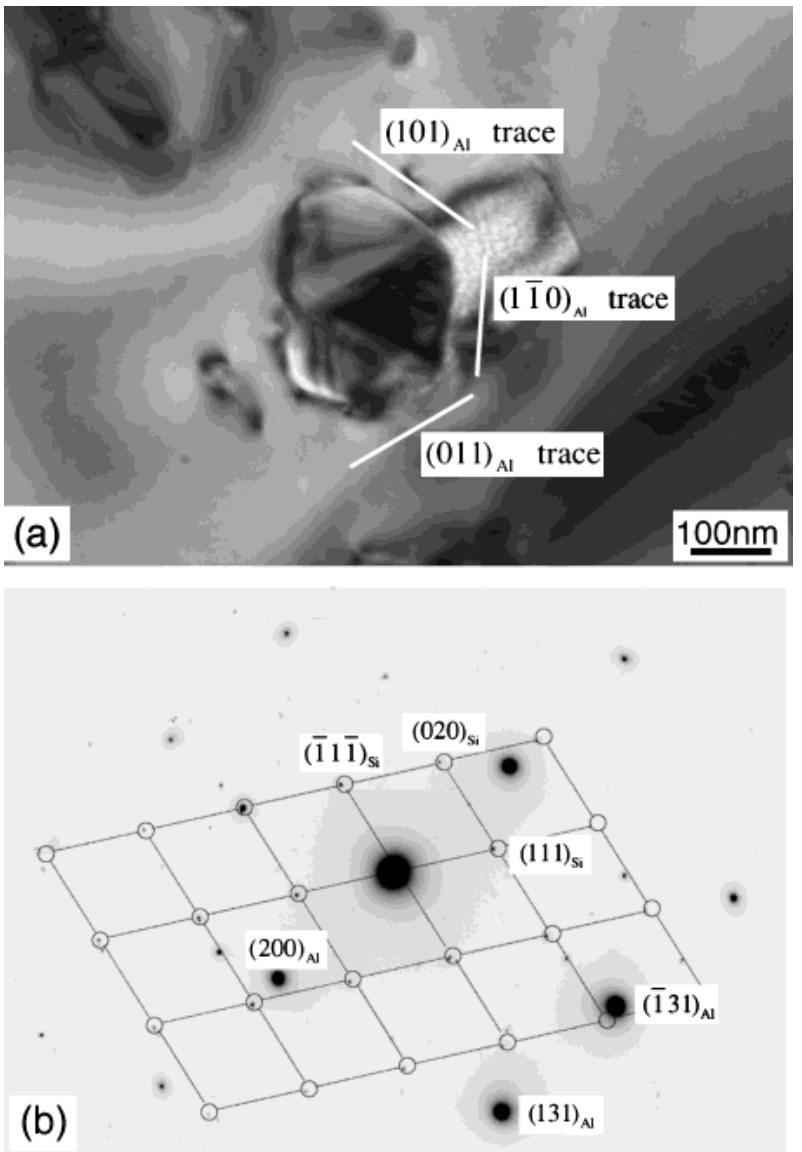

Fig. 17 Precipitation of Si particles in the excess Si alloy 6 aged at $300^{\circ} \mathrm{C}$ for $10 \mathrm{~h}$. (a) Bright field image and (b) the selected area electron diffraction pattern.

the previous studies, ${ }^{8,18)}$ the formation of other intermediate phases is examined here. In the excess Si alloys, Type A rods starts to precipitate after $\beta^{\prime \prime}$ needle and fine Si particle formation at $210^{\circ} \mathrm{C}$. The average diameter of Type-A rods is extremely thick, i.e., $80-100 \mathrm{~nm}$. The fact that Type-A rods precipitate easily at temperatures as low as $210^{\circ} \mathrm{C}$ implies that they form without large partition of solute atoms. This is because the nucleation and growth depend largely on the solute atom diffusion. It has been reported by Matsuda et al. ${ }^{9,11)}$ that the chemical composition of $\beta^{\prime \prime}$ phase is $\mathrm{Si}: \mathrm{Al}: \mathrm{Mg}=6: 3: 1$ and that of Type-A phase is $\mathrm{Si}: \mathrm{Al}: \mathrm{Mg}=5: 4: 1$. Therefore, if some $\beta^{\prime \prime}$ needles transform into Type-A rods with absorbing $\mathrm{Al}$ atoms from the adjacent $\mathrm{Al}$ matrix in-situ fashion, the growth of Type-A will be achieved by small partition of alloying elements. Considering that the growth direction and the interplanar spacing of $(020)_{\beta^{\prime \prime}}$ for $\beta^{\prime \prime}$ needles ${ }^{16)}$ are $[010]_{\beta} \|\langle 001\rangle_{\mathrm{Al}}$ and $0.2025 \mathrm{~nm}$, and that the growth direction and the interplanar spacing of $(1 \overline{2} 10)_{\mathrm{A}}$ for Type-A rods ${ }^{10)}$ are $[1 \overline{2} 10]_{\mathrm{A}} \|\langle 001\rangle_{\mathrm{Al}}$ and $0.2025 \mathrm{~nm}$, respectively, it is likely that the in-situ transformation occurs. This may be the reason that such a coarse Type-A rod can precipitate at temperatures as low as $210^{\circ} \mathrm{C}$. It should be noted that cuboid $\beta$ particles do not precipitate after $\beta^{\prime \prime}$ precipitation in the excess $\mathrm{Si}$ alloys isothermally aged at $210^{\circ} \mathrm{C}$ although the precipitation reactions described above occur. This is a quite large difference from the precipitation sequence during the continuous
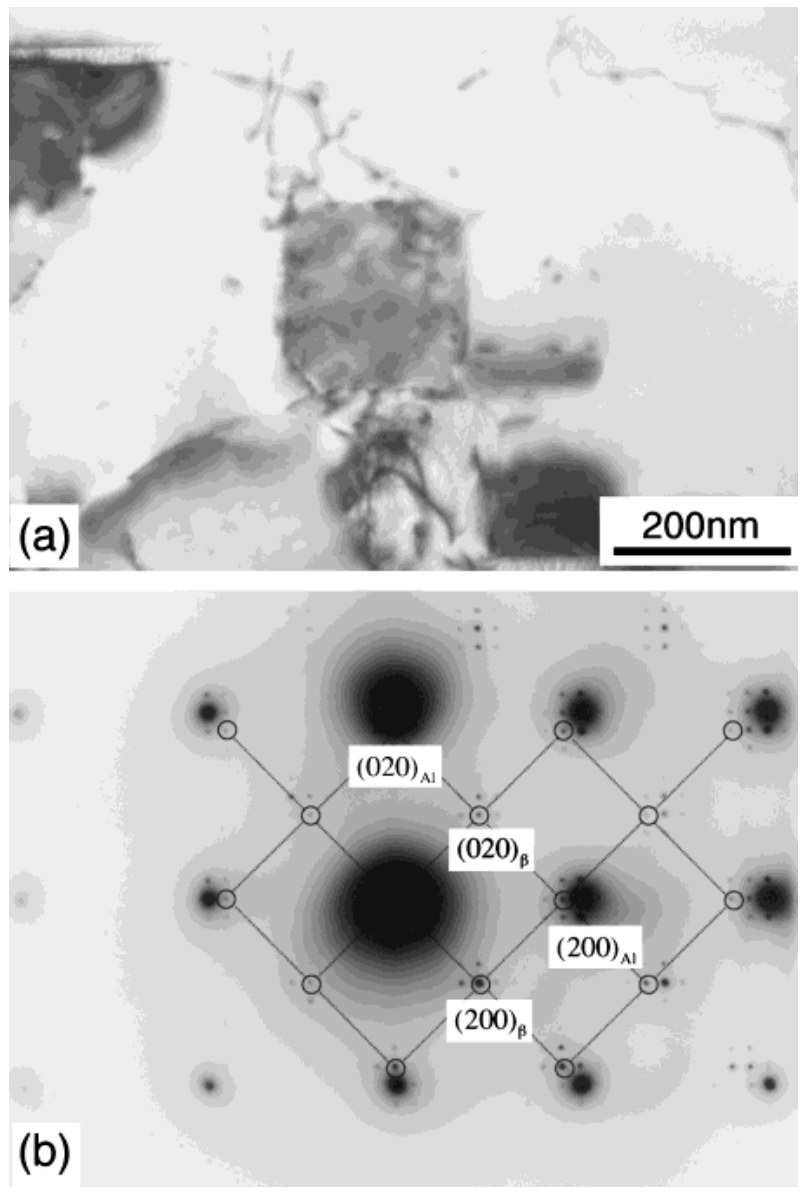

Fig. 18 Precipitation of $\beta$ plates in the excess Si alloy 6 aged at $350^{\circ} \mathrm{C}$ for $4 \mathrm{~h}$. (a) Bright field image and (b) the selected area electron diffraction pattern.

heating. ${ }^{8)}$

At $245^{\circ} \mathrm{C}$, although the ageing processes in the excess $\mathrm{Mg}$ and the quasi-binary alloys are accelerated significantly in comparison with those at $210^{\circ} \mathrm{C}$, the precipitation sequences are basically the same. In the quasi-binary alloy, it has so far been believed that the reaction occurring immediately after $\beta^{\prime \prime}$ precipitation is the precipitation of $\beta^{\prime}$ rods. In the previous study, however, it was confirmed that the reaction after $\beta^{\prime \prime}$ precipitation is the precipitation of cuboid $\beta$ particles. $\left.{ }^{8}\right)$ This result is in keeping with the present isothermal ageing result as far as the excess $\mathrm{Mg}$ and the quasi-binary alloys are concerned. It should be noted that $\beta^{\prime}$ rods precipitate at quite later stage of ageing after the formation of cuboid $\beta$ particles in the excess $\mathrm{Mg}$ alloy and the quasi-binary alloys. But the ageing sequence in the excess Si alloys is different and quite similar to that of the ageing at $210^{\circ} \mathrm{C}$.

In the case of ageing at temperatures $300-350^{\circ} \mathrm{C}$, the reactions are much accelerated in the excess $\mathrm{Mg}$ and the quasibinary alloys but those for the excess Si alloys are significantly different from the reactions in the alloys aged at temperatures below $245^{\circ} \mathrm{C}$. By ageing at these temperatures, Type-B and $\beta^{\prime}$ rods form in addition to Type-A rods. It is interesting to note that the precipitation sequence of rodlike precipitates in the excess $\mathrm{Si}$ alloys is: coarse TypeA rods $\rightarrow$ relatively thin Type-B rods $\rightarrow$ relatively thin $\beta^{\prime}$ rods. Such a sequence can be understood by considering the 
chemical compositions of the intermediate phases determined by Matsuda et al., i.e., Si:Al:Mg = 5:4:1 for Type-A, ${ }^{9,11)}$ $\mathrm{Si}: \mathrm{Al}: \mathrm{Mg}=5: 4: 2$ for Type-B ${ }^{10,11)}$ and $\mathrm{Si}: \mathrm{Al}: \mathrm{Mg}=1: 0: 2$ for $\beta^{\prime}$ rods. ${ }^{1,19,21)}$ It is only necessary for the formation of TypeA rods from $\beta^{\prime \prime}$ needles to absorb small amounts of $\mathrm{Al}$ atoms from the matrix as described above. In the case of Type$\mathrm{B}$ precipitation from $\beta^{\prime \prime}$ needles, some additional $\mathrm{Mg}$ atoms should be absorbed. For the formation of $\beta^{\prime}$ rods, complete re-partition of the chemical composition is prerequisite because $\beta^{\prime}$ phase does not contain $\mathrm{Al}$ atoms with $\mathrm{Mg}_{2} \mathrm{Si}$ composition. The precipitation sequence determined in the present study, however, is contradict with that obtained by Matsuda et al., ${ }^{12)}$ i.e., $\beta^{\prime}$ rods $\rightarrow$ Type-B rods $\rightarrow$ Type-A in their study. Although the reason for it is not clear at present, it may arise from the difference in either the chemical composition or the ageing temperature. It should, however, be noted that the present sequence seems much reasonable in view of the compositions of the intermediate phases determined by Matsuda et al. Type-C rods could not be detected in the present alloys.

\section{Conclusions}

The effects of excess $\mathrm{Mg}$ and $\mathrm{Si}$ contents on the isothermal ageing processes of $\mathrm{Al}-\mathrm{Mg}_{2} \mathrm{Si}$ alloys have been investigated mainly by means of transmission electron microscopy. The precipitation behaviours observed were largely different from those recognised during continuous ageing at a constant heating rate. The results are summarised as follows.

(1) Large age hardening arises from the precipitation $\beta^{\prime \prime}$ needles as has been reported so far.

(2) After the formation of $\beta^{\prime \prime}$ needles, cuboid $\beta$ particles precipitate and the following reaction is the precipitation of $\beta^{\prime}$ rods and then $\beta$ plates form in the excess $\mathrm{Mg}$ and the quasibinary alloys, but fine $\mathrm{Si}$ particles nucleate in the excess $\mathrm{Si}$ alloys.

(3) In the excess Si alloys, rodlike precipitates form after the precipitation of both $\beta^{\prime \prime}$ needles and Si particles in the sequence as: coarse Type-A rods $\rightarrow$ relatively thin Type$\mathrm{B}$ rods $\rightarrow$ relatively thin $\beta^{\prime}$ rods. This precipitation sequence can be understood by considering the chemical compositions of them determined by Matsuda et al..$^{9-11,18,21)}$

(4) The orientation relationships between these interme- diate phases and the $\alpha$ matrix are in good agreement with those reported so far.

(5) Two types of $\mathrm{Si} / \alpha$ matrix orientation relationships different from that obtained by Matsuda et al. ${ }^{20)}$ were determined.

\section{Acknowledgements}

Y. O., K. N. and S. K. would like to express sincere thanks to the Ministry of Education and Science for providing the Research Grant-in-Aids. L. C. D. would like to thank The Rotary Club for providing the scholarship for this research.

\section{REFERENCES}

1) G. Thomas: J. Inst. Metals. 90 (1961-2) 57-63.

2) M. H. Jacobs: Philos. Mag. 26 (1972) 1-13.

3) P. Barczy and F. Trante: Scand. J. Metals 4 (1975) 284-292.

4) I. Dutta and S. M. Allen: J. Mater. Sci. Lett. 10 (1991) 323-326.

5) I. Dutta, S. M. Allen and J. L. Hafley: Metall. Trans. A 22A (1991) 2553-2563.

6) G. A. Edwards, K. S. Tiller, G. L. Dunlop and M. J. Couper: Acta Mater. 46 (1998) 3893-3904.

7) M. Kanno, H. Suzuki and Y. Shiraishi: J. Japan Inst. Metals 43 (1979) 81-86.

8) Y. Ohmori, L. C. Doan, Y. Matsuura, S. Kobayashi and K. Nakai: Mater. Trans. 42 (2001) 2576-2583.

9) K. Matsuda, S. Ikeno, T. Sato and A. Kamio: Scr. Mater. 32 (1995) 1175-1180.

10) K. Matsuda, S. Ikeno, T. Sato and A. Kamio: Scr. Mater. 34 (1996) 1797-1802.

11) K. Matsuda, T. Naoi, K. Fujii, Y. Uetani, T. Sato, A. Kamio and S. Ikeno: Mater. Sci. Eng. A262 (1999) 232-237.

12) K. Matsuda, Y. Sakaguchi, Y. Miyata, Y. Uetani, T. Sato, A. Kamio and S. Ikeno: J. Mater. Sci. 35 (2000) 179-189.

13) T. V. Shchegoleva: Phys. Met. Metallogr. 25 (1968) 56-59.

14) R. P. Wahi and M. von Heimendahl: Phys. Status. Solidi. (a) 24 (1974) 607-612.

15) J. P. Lynch, L. M. Brown and W. H. Jacobs: Acta Metall. 30 (1982) 1389-1395.

16) S. J. Andersen: Met. Mater. Trans. A 26A (1995) 1931-1937.

17) N. Maruyama, R. Uemori, N. Hashimoto, M. Saga and M. Kikuchi: Scr. Metall. 36 (1997) 89-93.

18) Y. Ohmori, L. C. Doan and K. Nakai: Mater. Trans. 43 (2002) in press.

19) K. Matsuda, S. Tada and S. Ikeno: J. Electron Microsc. 42 (1993) 1-6.

20) K. Matsuda, S. Tada and S. Ikeno: J. Japan Inst. Metals 58 (1994) 252259.

21) K. Matsuda, S. Ikeno and S. Tada: J. Japan Inst. Metals 57 (1993) 11071113. 